\title{
Late diagnosis and surgical treatment of patients diagnosed with unilateral congenital cataract at Fundación Visión, in Asuncion, Paraguay
}

\author{
Diagnóstico tardio e tratamento cirúrgico de pacientes diagnosticados com catarata congênita unilateral \\ na Fundación Visión, em Assunção, Paraguai
}

Manuel Zegarra ${ }^{1}$, Gisella Harumi Burga ${ }^{1}$, Van Lansingh ${ }^{2}$, Margarita Samudio ${ }^{3}$, Edgar Duarte ${ }^{1}$, Rocio Ferreira ${ }^{1}$, Yesenia Dorantes $^{1}$, Juan Carlos Ginés ${ }^{1}$, Luz Zepeda ${ }^{4}$

\begin{abstract}
Purpose: Providing data on the late diagnosis and surgical treatment of patients who underwent surgery for total unilateral congenital cataract.

Methods: Systematic retrospective review of the medical record of all patients between 0 and 16 years old with total unilateral congenital cataract who underwent surgery at Fundación Vision between January 2010 and July 2012.

Results: Medical records of 37 patients (51 \% females) were studied, age was 7.4 ( \pm 4.9) years (average \pm SD) and $62 \%$ lived on Departamento Central (the most populated region from Paraguay). A total of $97.3 \%$ patients underwent late surgical treatment and $86.5 \%$ received a late diagnosis. The average time elapsed between the diagnosis and the surgical treatment was one month, and $62.2 \%$ of the patients underwent surgery within six months from the diagnosis.

Conclusion: This study evidences that most of the patients in our series had a late treatment as a result of a late diagnosis. Based on these results we recommend establishing strategies to improve the early detection and surgical treatment of the newborns.

Keywords: Cataract/congenital; Cataract extraction; Late diagnosis; Visual acuity Paraguay
\end{abstract}

\section{RESUMO}

Objetivo: Fornecer dados sobre o diagnóstico tardio e o tratamento cirúrgico de pacientes submetidos à cirurgia de catarata congênita unilateral total.

Métodos: Análise retrospectiva sistemática do prontuário de todos os pacientes entre 0 e 16 anos de idade com catarata congênita unilateral total, e que se submeteram à cirurgia na Fundación Visão, entre janeiro de 2010 e julho de 2012.

Resultados: Prontuários de 37 pacientes (51\% mulheres) foram estudados, a idade foi de $7,4( \pm 4,9)$ anos (média \pm SD) e 62\% viviam no Departamento Central (a região mais populosa do Paraguai). Um total de $97,3 \%$ dos pacientes foi submetido ao tratamento cirúrgico tardio e 86,5\% apresentaram um diagnóstico tardio. O tempo médio decorrido entre o diagnóstico e o tratamento cirúrgico foi de um mês, e 62,2\% dos pacientes foram submetidos a cirurgia no prazo de seis meses a partir do diagnóstico. Conclusão: Este estudo evidencia que a maioria dos pacientes da nossa série teve um tratamento final tardio, como resultado de um diagnóstico tardio. Com base nesses resultados, recomendamos o estabelecimento de estratégias para melhorar a detecção precoce e o tratamento cirúrgico dos recém-nascidos.

Descritores: Catarata/congênita; Extração de catarata; Diagnóstico tardio; Acuidade visual; Paraguai

\section{INTRODUCTION}

Congenital cataract is described as the lens opacity in a newborn ${ }^{(1)}$. This disease is one of the main causes of infant treatable blindness, with an estimated occurrence of 1 to 15 per 10,000 newborns ${ }^{(2-4)}$. There is no local epidemiological data about this condition in Paraguay.

The congenital cataract causes functional amblyopia, which can be reversible if therapeutic measures are taken at a sensory plasticity stage ${ }^{(5,6)}$. The best period for treating the congenital cataract is within the first six weeks of age, for unilateral disease, and within the first 10 weeks of life, for bilateral cases. Bilateral cataract presents a more favorable visual diagnostic as they cause less amblyopia than the unilateral ones ${ }^{(7-10)}$.

Prevention of blindness caused by congenital cataract depends on early detection and on the availability of specialized equipment and medical staff trained in pediatric ophthalmology. Even though the pediatrician shall make a red reflex examination on all newborns (and it shall be repeated within the first three months of life), many studies conducted at different developing countries pointed to a late diagnostic, which limits the early surgical treatment to succeed in their visual rehabilitation ${ }^{(11-14)}$.

In many instances, due to the greater familiarity with the infant, it is the mother who first recognizes the leukocoria. A study conducted in Brazil reported that the mothers have recognized $38.6 \%$ of the cases, what reveals the inability of health care system in performing an early diagnosis ${ }^{(15-17)}$.

Currently, congenital cataract represents a challenge to the ophthalmologist who should perform the ocular globe anatomic restoration before two months of age so to prevent the amblyopia in the unilateral cataract. Treating a child is more complex than treating an adult, considering the greater inflammatory response on an infant, surgery time, and the needed aphakia rehabilitation to obtain a good result in the long run ${ }^{(18-20)}$.

The main purpose of this study is to provide data about the diagnostic and surgical treatment of patients who had their unilateral
Submitted for publication: April 2, 2014

Accepted for publication: September 12, 2014

Study conducted at Fundación Visión - Paraguay.

Fundación Visión, Universidad Católica Nuestra Señora de la Asunción, Asunción, Paraguay.

IAPB/V2020 Latin America, Weston, Florida, USA.

3 Instituto de Investigaciones en Ciencias de la Salud, Universidad Nacional de Asunción, Asunción,

Paraguay.

${ }^{4}$ Hospital Civil de Guadalajara, Universidad de Guadalajara, Guadalajara, Mexico.
Funding: No specific financial support was available for this study.

Disclosure of potential conflicts of interest: None of the authors have any potential conflicts of interest to disclose.

Corresponding author: Manuel Zegarra. Quartier Las Marías 5-108 - San Lorenzo - Paraguay Email: manuzegarra@gmail.com

Registered with the fundación visión's ethics committee under number: 002/2013. 
LATE DiAgNosis AND SURGICAL TREATMENT OF PATIENTS DiAgNOSED With UNILATERAL CONGENITAL CATARACT AT

Fundación Visión, in Asuncion, Paraguay

congenital cataract operated at Fundación Visión. This information will help the health care providers to develop strategies to reduce the late care of such a major disease.

\section{METHODS}

Medical records of all patients between 0 and 16 years old with diagnosis of total unilateral congenital cataract who underwent cataract surgery at Fundación Visión between January 2010 and July 2012 were reviewed. Patients with incomplete medical records or with systemic or ocular diseases were excluded. The study was approved by Fundación Visión's Ethics Committee, and was conducted according to the ethical standards set out by the Declaration of Helsinki.

The following data were studied: age, gender, provenance, age when the diagnosis was done at Fundación Visión, age when the surgery was performed, and the time elapsed between the diagnosis and the surgery. The cases in which the treatment happened after an age of 2 months were considered as late surgical cases.

The data were consigned in an electronic spreadsheet on Excel 6.0 (Microsoft, Redmond, WA, USA) and subsequently reviewed by the statistical package SPSS 11.5 (SPSS Inc., Chicago, IL) for Windows. Descriptive statistics was used for the socio-demographic characteristics, expressing the nominal variables such as relative and absolute frequency.

\section{RESULTS}

Thirty-seven patients, from the 43 who underwent a cataract surgery at Fundación Visión, between January 2010 and July 2012, met the inclusion criteria. Six patients were excluded due to incomplete data in their medical records or because they presented other systemic or ocular diseases.

Table 1 describes the patient demographic characteristics: 51\% were female; age was 7.4 ( \pm 4.9) years (average \pm standard deviation [SD]); $62 \%$ of the patient came from Departamento Central, including Asunción (the most populated region from Paraguay).

The diagnosis average time was 36 months, the surgical treatment average time was seven years, and the time elapsed between the diagnosis and surgical treatment average was one month (Table 2).

A total of $13.5 \%$ of the patients had the diagnosis for total unilateral congenital cataract within the first 2 months of age; $24.3 \%$ between the third and twelfth month of age, while for the majority (62.2\%) the diagnosis was done after 24 months (Table 3).

Surgery was performed after 2 months of age in $97.3 \%$, distributed between the third month and the twelfth month (2.7\%), between the first and fifth year (40.5\%) and after 5 years (54.1\%). Only $2.7 \%$ of the patients underwent surgery before 2 months of age (Table 4).

Once the diagnosis was done, $59.5 \%$ of the patients waited less than 2 months for the surgical treatment, 8.1\% waited between 3 and 6 months, $13.5 \%$ waited 12 months, and $18.9 \%$ waited at least 60 months (Table 5).

\section{DISCUSSION}

Congenital cataracts are an important cause for the visual impairment within the infantile population, particularly the total unilateral cataracts, who have not undergone an appropriate treatment. Our study verified that $97.3 \%$ of the patients underwent a surgical treatment after 2 months, and this delay may have caused impairment in binocular visual development, which may have resulted in deprivation amblyopia. Therefore, it is quite probable that the visual results were not optimum in this group, due to such late treatment. Our results are comparable to other studies conducted in developing countries such as Brazil, where a study verifies a similar delay in $95.5 \%$ of patients with congenital cataract ${ }^{(15)}$ and another study conducted in the same country verified that $88.8 \%$ of patients underwent surgery after six months of age ${ }^{(10)}$. Studies conducted in China showed
Table 1. Demographic characteristics of patients with unilateral congenital cataract at Fundación Visión $(n=37)$

\begin{tabular}{ll}
\hline Gender & \\
Female & $19(51 \%)$ \\
Male & $18(49 \%)$ \\
Age (years) & $7.4( \pm 4.9)$ \\
Provenance & \\
Departamento central (including asunción) & $23(62 \%)$ \\
Rest of the country & $14(38 \%)$ \\
\hline
\end{tabular}

* = average \pm standard deviation.

Table 2. Diagnostic and treatment delay of patients with unilateral congenital cataract at Fundación Visión, Paraguay $(n=37)$

\begin{tabular}{lcc}
\hline Delay & Average & Range \\
\hline Age at diagnosis & 36 months & 0 to 180 months \\
Age at surgery & 7 years & 2 months to 16 years \\
Time from diagnosis to surgery & 1 month & 0 to 193 months \\
\hline
\end{tabular}

Table 3. Diagnosis delay of patients with unilateral congenital cataract at Fundación Visión, Paraguay $(n=37)$

\begin{tabular}{lc}
\hline Age at diagnosis (months) & $\mathbf{n}(\%)$ \\
\hline$<2$ & $5(13.5 \%)$ \\
$3-12$ & $9(24.3 \%)$ \\
$13-24$ & 0 \\
$>24$ & $23(62.2 \%)$ \\
\hline
\end{tabular}

Table 4. Treatment delay of patients with unilateral congenital cataract at Fundación Visión, Paraguay $(n=37)$

\begin{tabular}{lc}
\hline Age at surgery (months) & $\mathbf{n}(\%)$ \\
\hline$<2$ & $1(2.7 \%)$ \\
$3-12$ & $1(2.7 \%)$ \\
$13-60$ & $15(40.5 \%)$ \\
$>60$ & $20(54.1 \%)$ \\
\hline
\end{tabular}

Table 5. Time elapsed between diagnosis and surgery of patients with unilateral congenital cataract at Fundación Visión, Paraguay $(n=37)$

\begin{tabular}{lc}
\hline Time between diagnosis and treatment (months) & $\mathbf{n ~ ( \% )}$ \\
\hline$<2$ & $22(59.5 \%)$ \\
$3-6$ & $3(8.1 \%)$ \\
$7-12$ & $5(13.5 \%)$ \\
$>60$ & $7(18.9 \%)$ \\
\hline
\end{tabular}

similar results: one of them reports that $98.8 \%$ of patients with unilateral congenital cataract underwent surgery after 6 months, and none of them within the first 12 weeks of age ${ }^{(11)}$. Another study in the same country verified that only $0.4 \%$ of the patients with congenital cataract were submitted to surgery before 12 weeks of age, and no patient was submitted to surgery within the first 8 weeks ${ }^{(8)}$.

The late treatment in our series was directly related to the late diagnosis, considering that $86.5 \%$ of the patients were diagnosed after 2 months of age, comparing to the studies conducted in Bra- 
zil, where $55.5 \%$ of the congenital cataracts was diagnosed after 2 months, and in China where $78 \%$ was diagnosed after 6 months of life ${ }^{(11,15)}$. In developed countries such as USA and UK, the diagnosis of the majority of patients with congenital cataract is done during the first month of life ${ }^{(14)}$. This observed delay could be explained by the failure in diagnosing the disease at birth, lack of information by the families and the impossibility of access to specialized services. This my evidence the barriers existing in countries like Paraguay, which include to the surgery itself, to the access to surgical services and the acceptance of the surgery $(8,11,13,15)$.

However, once the diagnosis and surgery indication are done, no excessive delay is observed. In our series, the average time elapsed for the surgical treatment following the medical diagnostic and surgery indication was one month; $62.2 \%$ having been submitted to surgery before 6 months, and $75.7 \%$ before 12 months. Our results were better than those of Tanzania, where only $39 \%$ of the patients were surgically treated within 6 months after having been diagnosed and $17 \%$ were operated between the seventh and twelfth month after having been diagnosed ${ }^{(13)}$.

A relatively high percentage $(18.9 \%)$ of our patients had a late surgical treatment of 5 or more years, coinciding with the work of Mwend et al ${ }^{(13)}$. It is well known that no great visual improvement is obtained with a late surgical treatment; however, the institutional policy is to carry it out, expecting at least some improvement. We found similarity in genders of the affected patients (male $49 \%$ and female $51 \%)$, what differs from the study conducted in Tanzania, where the male gender prevails over the female gender (2:1 ratio). This may be explained by cultural issues, which confer a greater importance on the male gender for his labor role.

Most of the patients in our series live close to Fundación Visión's central clinic (62\%), and this matches with the Tanzania study data, which reports that the children who live close to the hospital had a greater access to ophthalmologic care than the children who live far from the hospital|(13).

\section{CONCLUSION}

Unilateral congenital cataract is a disease that causes a severe visual impairment if no early surgical treatment is received. This pioneer study allows us to obtain objective data on the congenital cataract cases attended to in our institution, where we evidence that the late treatment results from a late diagnosis; therefore, we expose this problem in such a way to serve as a reference for the reality of our health care system. We suggest that investigations be carried out in such a way to allow us to determine the barriers and set up strategies (training of neonatologists, training of parents and implementation of a pediatric ophthalmologic service) to improve the newborn ex- ploration, favoring the early detection, surgical treatment and rehabilitation of children who suffer from this disease.

\section{REFERENCES}

1. Gilbert C, Foster A. Blindness in children: control priorities and research opportunities. Br J Ophthalmol. 2001;85(9):1025-7.

2. Gilbert C, Foster A. Childhood blindness in the context of VISION2020-The right to sight. Bull World Health Organ. 2001;79(3):227-32.

3. Arieta C, José NK. Catarata congênita: dificuldades no tratamento. Arq Bras Oftalmol. 1987;50(3):116-9.

4. Foster A, Gilbert C, Rahi J. Epidemiology of cataract in childhood: a global perspective. J Cataract Refract Surg. 1997; 23 Suppl. 1:601-4.

5. Borisovsky G, Silberberg G, Wygnanski- Jaffe T, Spierer A. Results of congenital cataract surgery with and without intraocular lens implantation in infants and children. Arch Clin Exp Ophthalmol. 2013;251(9):2205-11.

6. Lambert SR. Management of monocular congenital cataracts. Eye (Lond).1999;13(Pt 3b): 474-9. Comment in: Eye (Lond). 2000;14(Pt 1):120.

7. Lambert SR, Lynn MJ, Reeves R, Plager DA, Buckley EG, Wilson ME. Is there a latent period for the treatment of children with dense bilateral congenital cataracts? J AAPOS. 2006;10(1):30-6.

8. Zhang $H$, Xie L, Wu X, Tian J. Long-term results of pediatric cataract surgery after delayed diagnosis. J AAPOS. 2012;16(1):65-9.

9. Birch EE, Stager DR. The critical period for surgical treatment of dense congenital unilateral cataract. Invest Ophthalmol Vis Sci. 1996;37(8):1532-8

10. Ejzenbaum F, Salomão SR, Berezovsky A, Waiswol M, Tartarella MB, Sacai PY, et al. Amblyopia after unilateral infantile cataract extraction after six weeks of age. Arq Bras Oftalmol. 2009;72(5):645-9.

11. You C, Wu X, Zhang Y, Dai Y, Huang Y, Xie L. Visual impairment and delay in presentation for surgery in Chinese pediatric patients with cataract. Ophthalmology. 2011; 118(1):17-23. Comment in: Ophthalmology. 2011;118(8):1692; author reply 1692

12. Bronsard A, Geneau R. Shirima S, Courtright P, Mwende J. Why are children brought late for cataract surgery? Qualitative findings from Tanzania. Ophthalmic Epidemiol. 2008;15(6):383-8

13. Mwende J, Bronsard A, Mosha M, Bowman R, Geneau R, Courtright P. Delay in presentation to hospital for surgery for congenital and developmental cataract in Tanzania. Br J Ophthalmol. 2005;89(11):1478-82.

14. Chak M, Wade A, Rahi JS; British Congenital Cataract Interest Group. Long-term visual acuity and its predictors after surgery for congenital cataract: findings of the British Congenital Cataract Study. Invest Ophthalmol Vis Sci. 2006;47(10):4262-9.

15. Vidal R, Chaves L. Infantile cataract: the importance of early treatment and diagnosis, Arq Bras Oftalmol. 2005;68(3):299-305.

16. Gogate P, Khandekar R, Shrishrimal M, Dole K, Taras S, Kulkarni S, Ranade S,Deshpande M. Delayed presentation of cataracts in children: are they worth operating upon? Ophthalmic Epidemiol. 2010;17(1):25-33.

17. Ye HH, Deng DM, Qian YY, Lin Z, Chen WR. Long-term visual outcome of dense bilateral congenital cataract. Chin Med J (Engl). 2007;120(17):1494-7.

18. Sandomingo AF, Gómez JA, Carpio R, Gabarron MI, Peralta J, Sánchez E, et al. Cataratas infantiles. Actualización en cirugía oftálmica pediátrica. Segmento Anterior. 2007; 12(5):74-8.

19. Plager DA, Yang S, Nelly D, Spruger DT, Sondhi N. Complications in the first year following cataract surgery in infants. J AAPOS. 2002;6(1):9-14.

20. Lesueur L, Arné JL, Chapotot EC, Thouvenin D, Malecaze F. Visual outcome after pediatric cataract surgery: is age a major factor? Br J Ophthalmol. 1998;82(9):1022-5. 